\title{
Hubungan antara Sikap Pedagang Tentang Etika Promosi Terhadap Niat dan Perilaku Penjualan Rokok
}

\author{
Relationship Between Attitudes About The Ethical Promotion Of Cigarettes With The Intention And \\ Behavior Of Seling Cigarettes
}

\author{
Riantina Luxiarti ${ }^{1}$, Eko Maulana Syaputra ${ }^{2}$, \\ ${ }^{1}$ Program Studi D3 Rekam Medis \& Informasi Kesehatan Stikes Mahardika Cirebon \\ ${ }^{2}$ Program Studi Kesehatan Masyarakat Universitas Wiralodra ${ }^{2}$ \\ email : riantina@stikesmahardika.ac.id ${ }^{1}$ \\ ekomaulanasyaputra@unwir.ac.id ${ }^{2}$
}

\begin{abstract}
Abstrak
Latar Belakang : Sebagian besar remaja mulai merokok sebelum usia 18 tahun. Sekitar $70-80 \%$ remaja di Indonesia terpapar iklan rokok dari berbagai media. Indonesia mengatur peredaran dan promosi rokok dalam Peraturan Pemerintah Republik Indonesia Nomor 109 Tahun 2012. Berdasarkan observasi, terdapat pedagang yang melanggar peraturan tersebut. Pelanggaran tersebut dapat dikaji dengan menggunakan theory of planned behavior. Metode : Penelitian ini merupakan penelitian cross-sectional. Terdapat 2 lokasi penelitian, di daerah pertokoan di Kota Yogyakarta. Sampel adalah pedagang yang berjualan 100 meter di sekitar SMP atau SMA di lokasi penelitian. Sebanyak 71 responden diambil secara totality sampling. Data diambil dengan menggunakan kuesioner dan wawancara serta observasi. Hasil : Hasil uji chi-square menunjukkan, terdapat hubungan yang bermakna antara sikap tentang etika promosi rokok dengan niat (RP: 1,66) dan perilaku (RP: 1,29) menjual rokok kepada anak usia di bawah 18 tahun. Kesimpulan: Terdapat hubungan yang bermakna antara sikap pedagang tentang etika promosi rokok dengan niat dan perilaku menjual rokok ke anak usia di bawah 18 tahun.
\end{abstract}

Kata Kunci : merokok, teori perilaku terencana, sikap, rokok

\begin{abstract}
Background : Most of adolescence started consuming cigarette in age below ten years old. As much as $70-80 \%$ Indonesian adolescene face cigarette advertisement through some medias. Indonesian goverment has regulation related to cigarette promotion in Peraturan Pemerintah Repulik Indonesia Nomor 109 Tahun 2012. Such violations can be assessed with the Theory of planned behavior.

Method : This study was observational with cross sectional. There were two research sites, in the shopping center of Yogyakarta. Samples were sellers who sell cigarette about 100 meters from junior or high school sites. The total of 71 sample were taken by totality sampling method.

Results : The results of chi-square test showed a significant relationship between: Attitudes about the ethical promotion of cigarettes with the intention (RP: 1.66) and behavior of seling cigarettes to children under 18 years old (RP: 1.29).

Conclusion : There are significant correlation between attitudes about tobacco promotional ethics, about the rules of cigarettes distribution with the intentions and behavior of the selling cigarettes to children under 18 years old.
\end{abstract}

Keywords : smoking, theory of planned behavior, attitude,cigarettes

\section{Pendahuluan}

Jumlah perilaku merokok pada penduduk usia 15 tahun ke pada tahun 2015 masih tergolong tinggi yaitu sebesar 30,08\%, meskipun mengalami penurunan di tahun 2016 sebesar $1,11 \%$ yaitu menjadi 28.97. ${ }^{1}$ Iklan dan promosi industri tembakau merupakan penyebab remaja dan dewasa awal untuk mulai merokok serta melanjutkan merokok. Menurut data dari Global Youth Tobacco Survey (GYTS), sebanyak 81,5 \% siswa SMP dan 86,9\% siswa SMA terpapar iklan tembakau di toko-toko. Promosi rokok meningkatkan prevalensi remaja yang semula mencoba menjadi perokok aktif. ${ }^{2}$

Selain faktor maraknya iklan dan promosi rokok, kemudahan akses untuk memperoleh rokok turut menjadi faktor penguat perilaku merokok pada remaja. Berdasarkan hasil penelitian, sebanyak 
$85,7 \%$ remaja memperoleh rokok di sekitar sekolah dan rumah mereka. ${ }^{3}$ Langkah antisipatif yang diambil oleh Indonesia untuk mengatur peredaran dan promosi rokok tertuang dalam Peraturan Pemerintah Republik Indonesia Nomor 109 Tahun 2012. Pada kenyataannya, meskipun hukum ataupun peraturan telah ditetapkan di suatu negara, masih ditemukan pelangggaran terhadap hukum tersebut. Elf et al. dalam penelitiannya tentang Undang-Undang Cipta Tahun 2003 yang berisi larangan penjualan produk tembakau dan aturan periklanan rokok, menemukan bahwa terdapat banyak pelanggaran terhadap UU tersebut. Salah satu pelanggaran tersebut adalah dari 20 sekolah negeri dan 10 sekolah swasta, 87\% terdapat toko yang menjual tembakau di area 100 yard dari gerbang sekolah. Dari sebanyak 771 vendor yang diamati, 24\% dari vendor tersebut menjual produk tembakau, serta di sebanyak 57\% sekolah ditemukan iklan rokok yang melanggar hukum. ${ }^{4}$

Kota Yogyakarta terdapat banyak iklan, seperti baliho, banner yang dipasang di warung ataupun kios bahkan di pasang dekat lingkungan sekolah. ${ }^{5}$ Semakin gencar promosi yang dilakukan perusahaan rokok maupun keberadaan pedagang rokok di sekitar lingkungan sekolah, tentu akan memicu timbulnya perilaku merokok remaja. Berdasarkan observasi yang dilakukan oleh peneliti di beberapa pedagang yang berada di dekat sekolah menengah di daerah Kota Yogyakarta, ditemukan bahwa terdapat banyak anak yang membeli rokok dengan menggunakan seragam sekolah. Penelitian Oktavia dkk. menguatkan fakta tersebut bahwa sebanyak $85,7 \%$ remaja mengatakan rokok tersedia di sekitar sekolah dan rumah mereka. ${ }^{6}$ Pembelian rokok di outlet yang murah (tobacconists dan supermarket) secara signifikan 50\% lebih tinggi dibandingkan dengan pembelian rokok di outlet yang mahal. ${ }^{7}$ Perilaku pedagang tersebut merupakan salah satu pelanggaran terhadap penjualan rokok

Perilaku tersebut dapat dipengaruhi oleh sikap, norma subjektif, dan kontrol perilaku yang dirasakan pedagang terhadap penjualan rokok dan promosi rokok. Ajzen, menyebutkan dalam Theory of Planned Behavior bahwa sikap, norma subjektif, dan kontrol perilaku yang dirasakan mempengaruhi niat seseorang dalam berperilaku. ${ }^{8}$ Niat untuk mengubah perilaku, dianggap langsung terkait dengan perubahan perilaku. sikap membentuk keyakinan untuk melakukan perilaku atau tindakan. Niat menunjukkan banyaknya usaha yang dilakukan individu untuk berkomitmen dalam melakukan suatu perilaku. Tang et al menemukan bahwa ada hubungan yang signifikan antara 3 komponen Theory of Planned Behavior yaitu sikap, norma subjektif, dan kontrol perilaku yang dirasakan untuk menolak perjudian dengan niat untuk berjudi di Cina. ${ }^{9}$ Berdasarkan latar belakang di atas, penelitian terhadap sikap pedagang tentang etika promosi dan perilaku penjualan rokok yang dikaji dengan Theory of Planned Behavior (TPB) perlu untuk dilakukan. Penelitian ini bertujuan untuk mengetahui hubungan antara sikap pedagang tentang etika promosi rokok berdasarkan Peraturan Pemerintah No 109 Tahun 2012 dengan niat dan perilaku penjualan rokok.

\section{Metode Penelitian}

Penelitian ini merupakan penelitian observasional analitik dengan rancangan cross sectional. Penelitian ini dilakukan di 2 tempat, yaitu di wilayah pertokoan Malioboro dan pertokoan Jalan C. Simanjuntak. Daerah pertokoan ini berada di dekat sekolah menengah pertama dan sekolah menengah atas. Penelitian ini dilaksanakan pada bulan Juni 2016. Populasi dalam penelitian ini adalah semua jenis pedagang yang ada di daerah pertokoan Kota Yogyakarta. Sampel penelitin ini adalah pedagang/penjual segala merk rokok yang berada maksimal 100 meter dari gerbang sekolah sejumlah 71 pedagang. Pedagang dalam penelitian ini dibagi menjadi 3 macam, yaitu : a. Pedagang asongan : pedagang yang menjual rokok dengan membawa tempat dagangannya ke setiap tempat $b$. Pedagang warung kelontong : pedagang (pemilik) warung yang menjual makanan pokok dan menjual rokok. c. Pedagang angkringan : pedagang dorong yang menjual berbagai macam makanan dan minuman serta yang menjual rokok. Pengambilan sampel ini didasarkan kepada keterjangkaun anak-anak sekolah di 
bawah 18 tahun (menggunakan seragam sekolah) dalam memperoleh rokok saat istirahat maupun pulang sekolah. Pengambilan data menggunakan kuesioner. Data dianalisis menggunakan 2 uji statistik, yaitu 1. Data univariat diuji dengan menggunakan frekuensi, yang bertujuan untuk mengkategorikan variabel. 2, data bivariat diuji menggunakan Chi-square yang bertujuan untuk mengetahui hubungan antara variabel bebas dan variabel terikat.

\section{Hasil}

\section{A. Analisis Uivariat}

Tabel 1. Distribusi Frekuensi, Jenis Pedagang, Sikap Pedagang tentang Etika Promosi Rokok, Niat dan Perilaku dalam Menjual Rokok

\begin{tabular}{ccc}
\hline Variabel & Pedagang $(\mathbf{F})$ & \% \\
\hline Jenis pedagang & & \\
Angkringan & 22 & 31 \\
Warung & 44 & 62 \\
Asongan & 5 & 7 \\
\hline Sikap etika promosi rokok & & \\
Mendukung & 37 & 52,1 \\
Tidak mendukung & 34 & 47,9 \\
\hline Niat menjual rokok & & \\
Tidak menjual & 36 & 50,7 \\
Menjual & 35 & 49,3 \\
\hline Perilaku menjual rokok & & 19,7 \\
Tidak menjual & 14 & 80,3 \\
Menjual & 57 &
\end{tabular}

Berdasarkan Tabel 1, Sebagian besar jenis pedagang rokok dalam penelitian adalah pedanga warung sebanyak $62 \%$. Sikap pedagang tentang etika promosi rokok, yang mendukung sebesar $52,1 \%$. Sebanyak $50,7 \%$ pedagang memiliki niat untuk tidak menjual rokok kepada anak usia di bawah 18 tahun, sedangkan 80,3\% pedagang berperilaku menjual rokok kepada anak usia di bawah 18 tahun.

\section{B. Analisis Bivariat}

Tabel 2. Hubungan Antara Sikap Pedagang Tentang Etika Promosi Rokok Dengan Niat Dalam Menjual Rokok Kepada Anak Usia Di Bawah 18 Tahun

\begin{tabular}{|c|c|c|c|c|c|c|}
\hline \multirow[t]{3}{*}{ Variabel } & \multicolumn{4}{|c|}{$\begin{array}{c}\text { Niat menjual rokok anak usia } \\
\text { di bawah } 18 \text { tahun }\end{array}$} & \multirow{3}{*}{$\mathrm{RP}$} & \multirow{3}{*}{$\begin{array}{l}P \\
\text { value }\end{array}$} \\
\hline & \multicolumn{2}{|c|}{ Menjual } & \multicolumn{2}{|c|}{ Tidak menjual } & & \\
\hline & $\mathrm{N}$ & $\%$ & $\mathrm{~N}$ & $\%$ & & \\
\hline \multicolumn{7}{|c|}{$\begin{array}{l}\text { Sikap tentang etika promosi } \\
\text { rokok }\end{array}$} \\
\hline Tidak mendukung & 21 & 61,8 & 13 & 38,2 & 1,66 & $0,044 *$ \\
\hline Mendukung & 14 & 37,8 & 23 & 62.2 & & \\
\hline
\end{tabular}


Berdasarkan Tabel 2, responden yang memiliki sikap tidak mendukung etika promosi rokok yang memiliki niat menjual rokok kepada anak usia di bawah 18 tahun 1,66 kali lebih besar dibandingkan dengan responden yang mendukung etika promosi rokok. Hasil tersebut bermakna secara statistik.

Tabel 3. Hubungan Antara Sikap Pedagang Tentang Etika Promosi Rokok Dengan Perilaku Alam Menjual Rokok Kepada Anak Usia Di Bawah 18 Tahun

\begin{tabular}{|c|c|c|c|c|c|c|}
\hline \multirow[t]{3}{*}{ Variabel } & \multicolumn{4}{|c|}{$\begin{array}{c}\text { Perilaku menjual rokok anak } \\
\text { usia di bawah } 18 \text { tahun }\end{array}$} & \multirow[t]{3}{*}{$\mathrm{RP}$} & \multirow{3}{*}{$\begin{array}{l}P \\
\text { value }\end{array}$} \\
\hline & \multicolumn{2}{|c|}{ Menjual } & \multicolumn{2}{|c|}{ Tidak menjual } & & \\
\hline & $\mathrm{N}$ & $\%$ & $\mathrm{~N}$ & $\%$ & & \\
\hline \multicolumn{7}{|c|}{$\begin{array}{l}\text { Sikap tentang etika promosi } \\
\text { rokok }\end{array}$} \\
\hline Tidak mendukung & 31 & 91,2 & 3 & 8,8 & 1,29 & $0,027 *$ \\
\hline Mendukung & 26 & 70,3 & 11 & 29.7 & & \\
\hline
\end{tabular}

Berdasarkan Tabel 3 , responden yang memiliki sikap tidak mendukung etika promosi rokok yang memiliki perilaku menjual rokok ke anak usia di bawah 18 tahun lebih besar peluangnya dibandingkan dengan responden yang memiliki sikap mendukung aturan peredaran rokok. Hasil tersebut bermakna secara statistik

\section{Pembahasan}

Peraturan yang berlaku saat ini di Indonesia adalah Peraturan Pemerintah Republik Indonesia Nomor 109 Tahun 2012. ${ }^{10}$ Peraturan ini berisikan tentang pengamanan bahan yang mengandung zat adiktif berupa produk tembakau bagi kesehatan. Etika promosi rokok yang dimaksud dalam penelitian ini adalah aturan yang merujuk pada Peraturan Pemerintah No 109 Tahun 2012 tentang aturan promosi produk tembakau. Peredaran rokok terdapat dalam bagian ketiga, yaitu pada : 1. Pasal 25, pasal 45, pasal 46, dan pasal 47. Ketentuan dalam pengendalian promosi produk tembakau sebagaimana dimaksud yaitu sebagai berikut: a. tidak memberikan secara cuma-cuma, potongan harga, hadiah produk tembakau, atau produk lainnya yang dikaitkan dengan produk tembakau, b. tidak menggunakan logo dan/atau merek produk tembakau pada produk atau barang bukan produk tembakau; dan c. tidak menggunakan logo dan/atau merek produk tembakau pada suatu kegiatan lembaga dan/atau perorangan. ${ }^{7}$

Sikap merupakan respon evaluasi dari perasaan seseorang terhadap suatu objek yang berbentuk mendukung atau tidak mendukung terhadap sesuatu. Sikap merupakan hasil dari proses evaluasi diri seseorang yang berupa kesimpulan baik, buruk, positif-negatif, menyenangkan dan tidak menyenangkan. Pembentukan sikap dipengaruhi oleh beberapa faktor, yaitu pengalaman 10 pribadi, kebudayaan, orang lain yang dianggap penting, media massa, institusi atau lembaga pendidikan dan lembaga agama, serta faktor emosi dalam diri seseorang. ${ }^{11}$

Dalam penelitian ini, sikap positif atau sikap responden yang mendukung adanya aturan/etika terhadap promosi rokok di atas rata-rata, yang sejalan dengan niat untuk tidak menjual rokok kepada anak usia di bawah 18 tahun. Hal ini sejalan dengan teori Ajzen yang menyebutkan bahwa sikap seseorang atau individu memiliki hubungan dengan niat berperilaku. ${ }^{8}$ Niat untuk mengubah perilaku, dianggap langsung terkait dengan perubahan perilaku. sikap membentuk keyakinan untuk melakukan perilaku atau tindakan. Niat perilaku adalah keputusan seseorang untuk melakukan atau tidak melakukan suatu perilaku tertentu. Niat perilaku juga dapat diartikan sebagai ukuran dari kemauan 
seseorang untuk melakukan perilaku tertentu. Niat menunjukkan banyaknya usaha yang dilakukan individu untuk berkomitmen dalam melakukan suatu perilaku. ${ }^{8}$. Sikap tentang etika peromosi rokok adalah penilaian atau pendapat pedagang terhadap aturan yang mengatur segala bentuk larangan kegiatan promosi rokok berdasarkan pada Peraturan Pemerintah No 109 Tahun 2012 (promosi melalui pembagian rokok gratis/potongan harga, sponsor kegiatan musik remaja, merchandise, sales promotion girl, baliho dan iklan di TV).

Terdapat hubungan yang bermakna antara sikap etika promosi rokok dengan niat dan perilaku pedagang dalam menjual rokok kepada anak usia di bawah 18 tahun dengan p value 0,044 dan 0,027. Responden yang memiliki sikap yang tidak mendukung terhadap etika promosi rokok memiliki niat menjual rokok kepada anak usia di bawah 18 tahun 1,66 kali lebih besar dibandingkan dengan responden yang mendukung terhadap etika promosi rokok. Responden yang memiliki sikap yang tidak mendukung etika promosi rokok memiliki perilaku menjual rokok kepada anak usia di bawah 18 tahun, 1,29 kali lebih besar dibandingkan dengan responden yang mendukung etika promosi rokok. Kedua hasil tersebut bermakna secara statistik. Dalam penelitian ini, sikap etika promosi rokok pedagang yang mendukung berada di atas rata-rata, yang sejalan dengan niat untuk tidak menjual rokok kepada anak usia di bawah 18 tahun.

Hal ini sejalan dengan teori Ajzen yang menyebutkan bahwa sikap seseorang atau individu memiliki hubungan dengan niat berperilaku. Pada dasarnya, responden mendukung peraturan pemerintah yang memuat batasan terhadap promosi rokok, yang selama ini dilakukan oleh berbagai perusahaan rokok dalam menjual rokok ke anak usia di bawah 18 tahun. Hal ini tercermin dalam hasil, yaitu sebanyak 47,9\% responden yang merasa terganggu dengan baliho-baliho yang dipajang sepanjang jalan raya. Hal ini diperkuat oleh hasil wawancara terstruktur yang dilakukan peneliti, bahwa sebagian besar responden setuju dengan adanya peraturan pemerintah yang mengatur ketentuan dalam promosi menjual rokok yang dilakukan oleh perusahaan.

Berdasarkan hasil wawancara, terungkap hal menarik dalam penelitian ini bahwa salah satu trik promosi yang dilakukan oleh pedagang dalam menjual rokok adalah dengan memberikan harga sangat murah dan memperbolehkan rokok untuk diecer agar anak sekolah (usia di bawah 18 tahun) mampu membeli rokok. Bentuk promosi rokok lainnya yang sering terdapat di Indonesia untuk lebih mendekatkan diri kepada masyarakat adalah dengan mengadakan aneka games yang bisa diikuti oleh setiap orang, bahkan anak-anak sekalipun. Para pemenang games akan mendapat hadiah berupa barang-barang fungsional yang didisain dengan logo, warna atau merek rokok. Seperti, baju, payung, cangkir, jam dinding, tas, topi, diary, ballpoint dan lain-lain. ${ }^{12}$

Hasil penelitian ini sejalan dengan penelitian yang dilakukan oleh Indrawani dkk yang menemukan bahwa ada hubungan antara sikap terhadap label kemasan peringatan bahaya merokok dengan intensi berhenti merokok dengan $\mathrm{p}$ value $=0,034^{13}$. Penelitian ini didukung oleh hasil penelitian yang dilakukan oleh Sentosa yang menemukan bahwa ada hubungan antara sikap terhadap perilaku dengan niat memakai bebat pada butch dengan nilai $p$ value $0,000 .{ }^{14}$ Hasil ini juga sesuai dengan yang ditemukan oleh Javadi et al bahwa ada hubungan antara sikap dengan perilaku konsumen dalam perilaku belanja online konsumen. ${ }^{15}$

\section{Kesimpulan}

Terdapat hubungan antara sikap pedagang tentang etika promosi dengan niat dan perilaku menjual rokok. Pedagang yang memiliki sikap tidak mendukung etika promosi rokok memiliki niat dan perilaku menjual rokok kepada anak usia di bawah 18 lebih besar dibandingkan dengan responden yang mendukung etika promosi rokok. 


\section{Saran}

Pemerintah Daerah sebaiknya membuat kebijakan tentang perijinan menjual rokok dengan jarak lebih dari 100 meter agar lokasi menjual rokok tidak mudah diakses oleh anak-anak usia di bawah 18 tahun (anak sekolah). Selain itu juga, pemberian sanksi yang tegas terhadap pedagang atau semua orang yang melanggar peraturan tersebut.

\section{Daftar Pustaka}

1. BPS. 2016. Persentase Merokok Pada Penduduk Umur $\geq 15$ Tahun Menurut Provinsi https://www.bps.go.id/. Jakarta.

2. WHO.2015. WHO global report on trends in prevalence of tobacco smoking 2000-2025. http://www.who.int/tobacco/publications/surveillance/reportontrendstobaccos moking/en/.

3. Riskesdas, 2013. Riset kesehatan Dasar 2013. Jakarta.

4. Elf, J.L., Modi. B., Stillman.F., Dave.P. and Apelberg. P. 2013. Tobacco Sales and Marketing within 100 Yards of Schools in Ahmedabad City, India. Journal of Public Health 12 7. PP.4 4 2e4 48

5. Trisnowati. H. 2012. Paparan Iklan Rokok dan Perilaku Merokok pada Remaja SMP di Kabupaten Bantul Daerah Istemewa Yogyakarta Tahun 2011. Tesis. Program Pasca Sarjana UGM, Yogyakarta.

6. Oktavia, K., Joko, D., Meiyetriani, E dan Apriningsih. 2013. Panah Tajam Iklan Rokok di Televisi untuk Anak Muda. Proceding ICTOH

7. Burton, S., Clark.L., Heuler. S, Bollerup, J., Jackson. K, 2011. Retail Tobacco Distribution in Australia: Evidence for Policy Development. Australasian Marketing Journal 19. PP. 168-173

8. Ajzen, I. 2005. Attitude, Personality and Behaviour. 2nd edition. England : Open University. Press

9. Tang. C.S., and Wu, A.M.S. 2012. Problem Gambling of Chinese Collage Student Aplication of The Theory of Planned Behavior. Journal of Gamble Stud. 28:315-324.

10. Peraturan Pemerintah No 109 Tahun 2012. Tentang Pengamanan Bahan yang Mengandung Zat Adiktif Berupa Produk Tembakau bagi Kesehatan. Jakarta.

11. Azwar, S. 2013. Sikap Manusia Teori dan Pengukurannya. Edisi ke 2. Yogyakarta : Pustaka Pelajar.

12. Salim, A.D. 2013. IMC: Promosi, Iklan \& Sponsor Rokok Strategi Perusahaan Menggiring Remaja untuk Merokok. BENEFFIT Jurnal Manjaemen \& Bisnis. Vol 17 No 1. 56-58

13. Indrawani, S,N., Mailani, L \& Nilawati, N. 2014. Intensi Berhenti Merokok : Peran Sikap terhadap Perigatan pada Bungkus Rokok \& Perceived Behaviour Control. Jurnal Pemikiran \& Penelitian Psikologi. Vol 9 No 2. 65-73

14. Sentosa, I. 2016. Analisis Niat Memakai Bebat pada Butch dengan Teori Perilaku Terencana: Calyptra. Jurnal Ilmiah Mahasiswa. Vol 5 No 1. 16. Universitas Surabaya.

15. Javadi, M.H.m., Dolatabadi, H.R., Nourbakhsh, M., Poursaedi, A., \& Asadollahi, A.R. 2012. An Analysis of Factors Affectiig on Online Shopping Behaviour of Consumers. International Journal of Marketing Studies, 4 (5) 81-98. 